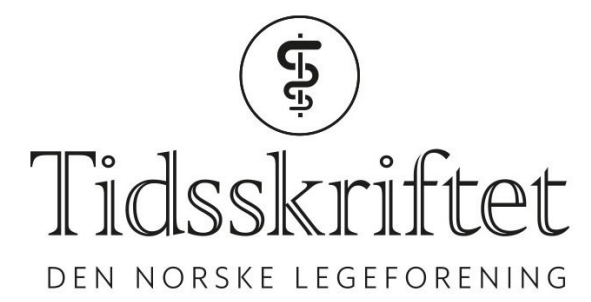

\title{
Antidiabetika er bare en del av god diabetesbehandling!
}

KOMMENTAR

\section{KÅRE I. BIRKELAND}

E-post: k.i.birkeland@medisin.uio.no

Kåre I. Birkeland er professor og overlege ved Klinikk for inflammasjonsmedisin og transplantasjon, Universitetet i Oslo og Oslo universitetssykehus. Han er leder av Helsedirektoratets arbeidsgruppe for «Medikamentell blodsukkersenkende behandling» ved utarbeidelse av Nasjonal faglig retningslinje for diabetes. Innlegget er diskutert med og godkjent av arbeidsgruppen.

Oppgitte interessekonflikter: Forfatter har holdt foredrag, ledet møter eller deltatt i rådgivningsgrupper for følgende firmaer som markedsfører diabetesmedikamenter i Norge med godtgjørelse til min arbeidsgiver: Novo Nordisk, Eli Lilly, sanofi-aventis, MSD, Boehringer Ingelheim, Bristol-Myers Squibb, Novartis, Pfizer, Janssen AS, Eli Lilly Norge. Han mottar honorar for å lede Medisinsk Fagråd i Diabetesforbundet, deltok ved utarbeidelsen av Nasjonal faglig retningslinje for diabetes, Helsedirektoratet 2016, og er medlem av Nasjonalt fagråd for diabetes.

Takk til Svingen og Løland som oppsummerer litt av den kunnskapen som er vunnet om antidiabetikas effekter ved makrovaskulær sykdom gjennom de senere års studier (1). Forfatterne er kritiske til noen av anbefalingene i den nye Nasjonal faglig retningslinje for diabetes og «inviterer til debatt om bruken av antidiabetiske midler for å redusere kardiovaskulær sykelighet og død blant pasienter med type 2 diabetes». En debatt om retningslinjene er svært velkommen. Men den bør ikke begrenses til de kardiovaskulære effektene av antidiabetika. Ikke minst er det grunn til å minne om viktigheten av god blodsukkerkontroll for å beskytte mot diabetiske nyre-, nerve- og øyeskader.

Hvis man tar seg tid til å lese anbefalingene i sin helhet, vil man se at moderne diabetesbehandling er mye mer enn bruk av antidiabetika. Det er derfor ikke riktig når kronikkforfatterne hevder at «behandlingsmålene for type 2-diabetes er primært rettet mot senkning av HbA1c». Tvert imot understreker retningslinjene at behandlingsmålene for diabetes handler om psykologiske forhold, kommunikasjon, motivasjon, kosthold og fysisk aktivitet som avgjørende faktorer for et godt og langt liv med diabetes. Ikke minst er egenbehandlingen svært viktig ved diabetes. Og det understrekes flere steder at god blodtrykksbehandling og lipidsenkende behandling er vel så viktig som blodsukkersenkende behandling som kardiovaskulær profylakse.

I anbefalingen er fem ulike medikamentgrupper likestilt som andrevalgsmedikament etter metformin. Det er nytt fra tidligere, og bygger nettopp på den nye kunnskapen som er fremkommet ved siste års forskning, slik det fremgår under arkfanene «Forskningsgrunnlag», «Begrunnelse» og «Praktisk i nettversjonen». Selv om flere av de nye medikamentene i enkeltstudier har vist lovende effekter på hjerte-/karsykdom og dødelighet, mente arbeidsgruppen da arbeidet ble avsluttet forsommeren 2016 at den samlede evidens når det gjelder bivirkningsprofil og effekt på viktige utfall som mortalitet, 
hjerteinfarkt, hjerneslag, blindhet, nyresvikt og livskvalitet ikke tilsa at enkelte av de fem medikamentgruppene burde fremheves foran andre. Vi skriver likevel en del om hvilke hensyn som kan tale for eller mot de ulike valgene. Ved gjennomgang av tilgjengelig vitenskapelig litteratur, fant vi heller ikke grunn for å advare mot bruken av sulfonylureapreparater, slik kronikkforfatterne og enkelte firmaer som markedsfører de nye legemidlene synes å mene. Ikke minst vil vi fremheve at valg av medikament i den aktuelle lege-pasientsituasjonen, i tillegg til å ta hensyn til vitenskapelig evidens må vektes mot legens erfaring og pasientens preferanser.

Det er gledelig at behandlingsmulighetene for type 2 diabetes utvides og vi ser en klar reduksjon i diabetiske senskader, både nasjonalt og internasjonalt. Det kommer stadig ny kunnskap fra gode vitenskapelige studier og det er derfor også planer om regelmessig revisjon av den nye Nasjonale faglige retningslinjen slik at anbefalingene er i tråd med oppdatert kunnskap.

\section{LITTERATUR:}

1. Svingen GFT, Løland KH. Antidiabetika ved type 2-diabetes - forvalter vi ny kunnskap riktig? Tidsskr Nor Legeforen 2017; 137: 1010 - 2. [PubMed]

Publisert: 2. oktober 2017. Tidsskr Nor Legeforen. DOI: 10.4045/tidsskr.17.0774

(C) Tidsskrift for Den norske legeforening 2020. Lastet ned fra tidsskriftet.no 